\title{
Compassion's More Dangerous Allies: Fear, Anxiety, and Amour-Propre
}

\author{
Alexandra Oprea, Australian National University
}

What kind of moral and sentimental education should we pursue under non-ideal circumstances? In states characterized by high inequality and imperfect political institutions, scholars have increasingly turned their attention to the ethics of care and the politics of compassion. In response, critics have raised concerns that compassion is too weak to serve politically salutary goals. Drawing on the moral and political psychology of Emile, this article shows that Rousseau relied on fear, anxiety, and amour-propre to extend compassion across class lines. Rousseau's account suggests that the proper development of compassion cannot do without these more "dangerous" allies, at least not in societies characterized by socioeconomic inequality. In addition to its contribution to Rousseau scholarship, the article adds to the contemporary literature on moral sentiments by highlighting three psychologically plausible and previously unacknowledged strategies for extending compassion: fear of downward social mobility, religious anxiety, and pride.

Keywords: compassion, inequality, fear, Rousseau, Emile, downward social mobility

$\mathrm{W}$

hat kind of moral and sentimental education should we pursue under nonideal circumstances? In states characterized by high inequality and imperfect political institutions, scholars have increasingly turned their attention to the ethics of care and the politics of compassion. ${ }^{1}$ Advocates and critics of compassion

I am grateful to Hannah Bondurant, Alexandra Ghit, Sair Goetz, Ruth Grant, Christopher R. Hallenbrook, Jeff Spinner-Halev, Daniel Stephens, Anil Venkatesh, Cynthia Wolters, Wenqing Zhao, the Duke Political Theory Workshop (especially Sam Bagg, Nolan Bennett, Eric Cheng, Michael Gillespie, Nora Hanagan, Michael C. Hawley, Christopher Kennedy, Antong Liu, Brian Spisiak, and Isak Tranvik) and the UNC Value Workshop. I also thank three anonymous reviewers from Polity, as well as editors Leonard Feldman and Roger Karapin, for constructive comments and conversations. Their input has significantly improved the manuscript.

1. Joan C. Tronto, Caring Democracy: Markets, Equality, and Justice (New York: New York University Press, 2013), especially 17-45; Virginia Held, The Ethics of Care: Personal, Political, and Global (Oxford, U.K.: Oxford University Press, 2005), especially 9-28; Eva Feder Kittay, Love’s Labor: Essays on Women, Equality, and Dependency (New York: Routledge, 1999), especially 117-39; Martha Nussbaum, "Compassion: The Basic Social Emotion," Social Philosophy and Policy 13 (1996): 27-58;

Published online March 12, 2020. https://doi.org/10.1086/708350

Polity, volume 52, number 2 (April 2020), pp. 189-220. 0032-3497/2020/5202-0003\$10.00.

(C) 2020 Northeastern Political Science Association. All rights reserved. 
both agree that Rousseau was one of the first political philosophers to consider its moral and political potential, particularly under unjust political regimes. ${ }^{2}$ Rousseau's most developed model for the cultivation of this potential appears within his educational treatise Emile, particularly in the education of the eponymous character. ${ }^{3}$ Fraistat, for example, has argued that Emile's compassion and care would enable the protagonist to avoid domination and its morally corrupting effects. ${ }^{4}$ Schaeffer has argued that Emile's education in compassion allows both him and Rousseau's readers to develop the type of political judgment appropriate for a citizen. ${ }^{5}$ As scholars have increasingly turned to Rousseau's Emile as a successful model of freedom, ${ }^{6}$ virtue, ${ }^{7}$ and even citizenship within commercial society, ${ }^{8}$ the case for the moral and political relevance of compassion appears stronger than ever.

However, this promise held out for compassion has faced increasingly vocal criticisms. Boyd identifies at least four pathologies that relate to compassion: mere voyeurism, pained avoidance, indifference to the out-group, and despondence about the human condition. ${ }^{9}$ Most of these pathologies are either amplified or created

Martha Nussbaum, Upheavals of Thought: The Intelligence of Emotions (Cambridge, U.K.: Cambridge University Press, 2001), 297-456; Martha Nussbaum, Political Emotions: Why Love Matters for Justice (Cambridge, Mass.: Harvard University Press, 2013), 137-60, 257-377; Martha Nussbaum, "Compassion and Terror," in The Politics of Compassion, ed. Michael Ure and Mervyn Frost (New York: Routledge, 2014), 189-207; Maureen Whitebrook, "Compassion as a Political Virtue," Political Studies 50 (2002): 529-44; Maureen Whitebrook, "Love and Anger as Political Virtues," in The Politics of Compassion, 21-36; and Elizabeth Porter, "Can Politics Practice Compassion?" Hypatia 21 (2006): 97-123.

2. Clifford Orwin, "Rousseau and the Discovery of Political Compassion," in The Legacy of Rousseau, ed. Clifford Orwin and Nathan Tarcov (Chicago: University of Chicago Press, 1997), 296-320, at 296.

3. Jean-Jacques Rousseau, Emile, or On Education, trans. Allan Bloom (New York: Basic Books, 1979), at 227, 235; and Jean-Jacques Rousseau, Oeuvres Complètes de Jean-Jacques Rousseau, ed. Bernard Gagnebin and Marcel Raymond (Paris: Gallimard, 1959), vol. IV, 511-512, 523. References to Rousseau's works are both to an English translation and to the Pléiade edition; some of the English translations have been modified.

4. Shawn Fraistat, "Domination and Care in Rousseau's Emile," American Political Science Review 110 (2016): 889-900.

5. Denise Schaeffer, Rousseau on Education, Freedom, and Judgment (University Park: Pennsylvania State University Press, 2013), at 85-106, 174-96.

6. Geneviève Rousselière, "Rousseau on Freedom in Commercial Society," American Journal of Political Science 60 (2016): 352-63.

7. Frederick Neuhouser, Rousseau's Theodicy of Self-Love: Evil, Rationality, and the Drive for Recognition (Oxford, U.K.: Oxford University Press, 2008).

8. Christopher Kelly, Rousseau as Author: Consecrating One's Life to the Truth (Chicago: University of Chicago Press, 2003); Schaeffer, Rousseau on Education (see note 5 above).

9. Richard Boyd, "Pity's Pathologies Portrayed: Rousseau and the Limits of Democratic Compassion," Political Theory 32 (2004): 519-46. 
by socioeconomic inequality and reach their apogee in corrupt political societies with persistent divisions among rich and poor. Precisely because of Rousseau's focus on the barriers of compassion between rich and poor, Orwin is concerned that political calls for compassion could end in political violence against the wealthy. ${ }^{10}$ Although compassion may have its limitations even in an egalitarian premodern society, the real limitations and failures of compassion, critics agree, are likely to emerge in pluralistic societies characterized by high socioeconomic inequalitythe very societies that advocates claim need compassion most. ${ }^{11}$

If this is the case, even the best recent defense of Rousseauian compassion falters on the problems of inequality. Marks has defended compassion as a supplement to justice that relies on three complementary aids: friendship, gratitude, and obligation. ${ }^{12}$ While Marks's account is compelling, he does not explicitly consider whether these allies are themselves weakened or limited in societies characterized by persistent inequality. In order to fortify Rousseau's discriminating defense of compassion, this article takes seriously the barriers to compassion created by socioeconomic inequality. The first section contributes to the literature on Rousseau and inequality by focusing on Emile-rather than on the commonly discussed Discourse on Inequality - to show the corrupting effects of inequality on moral sentiments. Given that Rousseau himself acknowledged the force of criticisms brought up by Boyd and Orwin, the next section then attends to his previously overlooked solution: the employment of dangerous but potent supplementary passions, such as fear, anxiety, and amour-propre, to extend compassion across class lines. The third section defends the model of a compassionate human being and citizen embodied by Emile as more realistic and politically salutary than critics generally acknowledge. In addition to contributing to scholarship on Rousseau, the conclusion returns to the contemporary conversation to defend the prima facie empirical plausibility of using fear, anxiety, and amour-propre to extend compassion in unequal societies.

\section{Barriers to Compassion: The Case of Socio-Economic Inequality}

In recent years, scholars have attended to Rousseau's analysis of the moral and political effects of inequality. According to Neuhouser and Williams, economic inequality

10. Orwin, "Discovery of Political Compassion," 310-12; his other concern is with the failure of attempts to institutionalize compassion, at 312-15 (see note 2 above).

11. Boyd, "Pity's Pathologies," 534 (see note 9 above); and Orwin, "Discovery of Political Compassion," 313-14 (see note 2 above).

12. Jonathan Marks, "Rousseau's Discriminating Defense of Compassion," American Political Science Review 10 (2007): 727-39. 
leads to domination, ${ }^{13}$ unhappiness, ${ }^{14}$ and the destruction of both natural goodness and the general will. ${ }^{15}$ By drawing on Emile, this article extends this recent conversation by investigating the effects of inequality on moral sentiments, particularly compassion. ${ }^{16}$ Compassion is connected to Emile's sense of justice and his capacity to form healthy relationships with others, including his family, ${ }^{17}$ his neighbors, ${ }^{18}$ his fellow-citizens, ${ }^{19}$ and his species. ${ }^{20}$ If inequality prevents compassion from developing to its mature and politically salutary form, this sentimental corruption would have further corrosive effects on the freedom, well-being, and happiness of individuals living in unequal political communities. This section begins with Rousseau's analysis of how substantial inequalities create psychological barriers to compassion. The following sections then turn to his deployment of fear, anxiety, and amour-propre in order to overcome these barriers.

Within Emile, Rousseau does not systematically disentangle economic inequality between rich and poor from social inequality between nobles and commoners. However, the book's discussion of both forms of inequality, which I refer to by the composite term "socioeconomic inequality," clarifies and extends the picture emerging from the Discourse on Inequality. In that work, the key moment where compassion was stifled (rather than just attenuated) took place after society crystalized into more permanent inequalities based on wealth and power ("every man's rank and fate set"). ${ }^{21} \mathrm{New}$ and more powerful passions such as amour-propre,

13. Frederick Neuhouser, "Rousseau's Critique of Inequality," Philosophy \& Public Affairs 41 (2013): 193-225, 196-204.

14. Ibid., 204-15.

15. David Lay Williams, "Forestalling 'the Ever-Widening Inequality of Fortunes': JeanJacques Rousseau on Economic Inequality and the General Will," paper presented at the Association for Political Theory Conference, Columbus, Ohio, October 2016, 1-41, at 11-19 and 19-27.

16. Although there are important differences between compassion, empathy, and sympathy, the precise boundaries of the concepts remain vigorously contested. Nussbaum defines compassion as involving concern for the suffering of another (Political Emotions, 142). In contrast, she describes empathy as a way of understanding and sharing the emotions of others (especially through the use of perspective taking) without the necessary addition of concern (Political Emotions, 145). Sympathy resembles compassion in including concern, but it is usually extended to emotional states other than suffering (including positive emotions such as joy). (See note 1 above).

17. Rousseau, Emile, 414, 440; and Rousseau, Oeuvres IV, 775, 811-12 (see note 3 above for both sources).

18. Rousseau, Emile, 435-36; and Rousseau, Oeuvres IV, 804-05.

19. Rousseau, Emile, 474; and Rousseau, Oeuvres IV, 859.

20. Rousseau, Emile, 226, 253; and Rousseau, Oeuvres IV, 511, 548.

21. Rousseau, Discourse on Inequality, 170; and Rousseau, Oeuvres III, 175 (see note 3 above). 
simultaneously inflaming and being inflamed by these inequalities, overwhelmed both "natural compassion and the still weak voice of justice" and resulted in violence and social collapse. ${ }^{22}$ By closely examining the psychological barriers to compassion in unequal societies, Emile both extends the analysis of the Discourse on Inequality and offers a model of overcoming these barriers that can plausibly apply at high levels of civilization and therefore socioeconomic inequality.

The three maxims of compassion in Book IV of Emile could have been called the three barriers to compassion. They include psychological and epistemic reasons why compassion often fails within unequal societies and hint at the potential educational solutions discussed in the next section. Rousseau's first maxim claims that it is beyond our psychological abilities to put ourselves in the place of those who are more fortunate [heureux]. ${ }^{23}$ Scholars usually interpret this maxim as a claim about our inability to empathize with the happiness of other people, where happiness refers to a psychological state or feeling. ${ }^{24}$ While I do not disagree that this interpretation is textually available, I want to suggest that Rousseau's discussion of compassion in this maxim is primarily concerned with barriers to identification created by differences in socioeconomic fortune. Rousseau's (brief) discussion of the maxim focuses on differences in socioeconomic status: "Thus one does not put oneself in the place of the rich or noble man to whom one is attached." ${ }^{25}$ He leaves room for one exception to the maxim, which he calls "the rural and pastoral life"- a description of a way of life and a particular socioeconomic status. ${ }^{26}$ What makes this condition (état) exceptional is its universal availability.

22. Jean-Jacques Rousseau, "Discourse on the Origin and Foundations of Inequality Among Men or Second Discourse," in The Discourses and Other Early Political Writings, ed. Victor Gourevitch (Cambridge, U.K.: Cambridge University Press, 1997), 111-222, at 171; see also Rousseau, Oeuvres III, 176 (see note 3 above).

23. Rousseau, Emile, 223; and Rousseau, Oeuvre IV, 506 (see note 3 above for both sources).

24. Dennis C. Rasmussen, The Problems and Promise of Commercial Society: Adam Smith's Response to Rousseau (University Park: Pennsylvania State University Press, 2008), 63; and Michael L. Frazer, "Reply to Critics," Adam Smith Review 7 (2013): 231-36, at 233. If we take Rousseau to deny the existence of positive empathy, he is not only on shaky psychological foundations, but later contradicts himself (cf. Rousseau, Emile, 251, 480; and Rousseau, Oeuvres IV, 545, 867; see note 3 above for both sources). However, if we take his claim to deny positive empathy across rigid class lines, there are to my knowledge no studies specifically testing this relationship. For a review of the literature on positive empathy, see Sylvia A. Morelli, Matthew D. Lieberman, and Jamil Zaki, "The Emerging Study of Positive Empathy," Social and Personality Psychology Compass 9 (2015): 57-68.

25. Rousseau, Emile, 223; and Rousseau, Oeuvres IV, 506. In the earlier version of the manuscript, Rousseau argues that one anticipates recompense for acts of compassion; see Rousseau, Emile, 223 n4; and Rousseau, Oeuvres IV, 506 n(a) (see note 3 above for both sources).

26. Rousseau, Emile, 223; and Rousseau, Oeuvres IV, 506 (see note 3 above for both sources). 
His claim that one need only want to "descend" to this condition distinguishes it from positions of wealth and power that are only available to a few. ${ }^{27}$ Finally, the conclusion to the maxim, which spells out the educational implications discussed in the following section, describes how a young man should relate to the "brilliant fortune" of others, further emphasizing the relevance of economic status. ${ }^{28}$

If the first maxim is focused on the failures of compassionate identification by the less fortunate for those more so, the second maxim provides a psychological mechanism through which those with higher socioeconomic and political status fail to feel compassion for those beneath them on the social ladder. Rousseau expects his readers to confirm from experience that the upper classes (the kings, the nobles, and the wealthy) rarely, if ever, concern themselves with the fate of their social inferiors (the subjects, the commoners, and the poor). ${ }^{29}$ The explanation revolves around what Nussbaum calls the judgment of similar possibilities. ${ }^{30}$ While Nussbaum rejects this judgment as a strictly necessary element of compassion, ${ }^{31}$ Rousseau regards the honestly felt possibility of experiencing similar misfortunes as indispensible for the moral education project: "do not hope to teach him to feel compassion for them [the sufferings of the unfortunate and the labors of the poor] if he considers them alien to him." ${ }^{32}$ As the next section shows, Rousseau's concern with preserving the judgment of similar possibilities and avoiding both

27. Rousseau, Emile, 223; and Rousseau, Oeuvres IV, 506 (see note 3 above for both sources).

28. Rousseau, Emile, 223; and Rousseau, Oeuvres IV, 507 (see note 3 above for both sources). It is also possible to interpret "le sort brillant des autres" as referring to other aspects of good fortune, such as good health or good luck in love.

29. Rousseau, Emile, 224; and Rousseau, Oeuvres IV, 507 (see note 3 above for both sources). There is at least some evidence to confirm that belonging to a higher social class negatively affects one's ability to empathize with others. See Michael E. W. Varnum, et al. "Social Class Affects Neural Empathic Responses," Culture and Brain 3 (2015): 122-30.

30. Nussbaum, Upheavals of Thought, 315 (see note 1 above).

31. Ibid., 317-19.

32. Rousseau, Emile, 224; and Rousseau, Oeuvres IV, 507 (see note 3 above for both sources). Nussbaum does not dispute this claim on empirical grounds, but rather provides an alternative explanation through which the judgment of similar possibilities may assist in simulating another person's experience (i.e., perspective taking), but the real work is done by the eudaimonistic judgment that the person's well being is important for one's own flourishing. Recent work in the neuroscience of empathy partly confirms Nussbaum's hypothesis; see Jean Decety and Jason M. Cowell, "Friends or Foes: Is Empathy Necessary for Moral Behavior?” Perspectives on Psvchological Science 9 (2014): 525-37. Further empirical research is required to determine whether Nussbaum or Rousseau provides the more compelling psychological account. Even if Rousseau is wrong about the judgment of similar possibilities, however, he does consider multiple paths to compassion, some of which begin with perspective-taking and lead to concern (e.g., fear of downward mobility) and others which begin with empathic concern (i.e., religious anxiety). For more details, see the next section in this article. 
envy for the rich and callousness for the poor requires him to appeal to fear and anxiety about the future for the first time in Emile's education. While Nussbaum regards fear as an enemy of compassion, ${ }^{33}$ Rousseau sees fear and anxiety as some of the most important, though dangerous, allies in the proper development of this sentiment.

The third maxim extends the second by emphasizing that, beyond a shared vulnerability to similar ills, compassion depends on underlying assumptions about the sentiments of the other, and therefore on our assumptions about their emotional and moral capacities. Rousseau claims that "the rich are consoled about the ill they do to the poor, because they assume the latter to be stupid enough to feel nothing of it." ${ }^{34}$ Without excluding the possibility that compassion requires that we attend to relevant differences with potential objects of our compassion, this maxim reminds the reader of the difficulty of identifying our shared humanity in societies characterized by persistent inequalities of wealth, status, and standing. The "man who thinks" can see "the same passions, the same sentiments in the hod-carrier and the illustrious man," but discerning these similarities behind the differences requires extensive sentimental, moral, and intellectual cultivation. ${ }^{35}$ The project of moral education in Emile allows him to see this common humanity behind these social divisions, but the maxims of compassion serve as a reminder of the difficulty of the task before him.

\section{The Dangerous Path to Mature Compassion}

Emile represents Rousseau's fullest account of moral cultivation within a society characterized by persistent inequalities. Given the maxims described in the previous section, compassion would be too weak on its own to overcome socioeconomic barriers. So far, Rousseau would seem to side with critics such as Boyd who expect compassion to fail in societies characterized by pervasive inequality. ${ }^{36}$ Marks's response that compassion is just weak enough to be politically safe would be unsatisfactory for either Rousseau or contemporary political theorists if it meant that its operation be restricted to one's friends, benefactors, and the group of those of similar socioeconomic status. ${ }^{37}$ Fortunately, Rousseau's discussion of compassion does not stop at the maxims, and he outlines a project of cultivating

33. Nussbaum, Political Emotions, 320-38 (see note 1 above).

34. Rousseau, Emile, 225; and Rousseau, Oeuvres IV, 509 (see note 3 above for both sources).

35. Rousseau, Emile, 225; and Rousseau, Oeuvres IV, 509 (see note 3 above for both sources).

36. Boyd, "Pity's Pathologies," 533-36 (see note 9 above).

37. Marks, "Discriminating Defense," 729-31 (see note 12 above). 
Emile's compassion to overcome these socioeconomic barriers. Marks is right that mature compassion operates alongside other pro-social sentiments and obligations. ${ }^{38}$ But before arriving at its salutary form, it must first operate independently of socioeconomic inequalities. Cultivating compassion to reach such a stage requires less reputable moral sentiments that defenders of compassion rarely address or deploy in service of extending compassion. In particular, Rousseau makes use of fear, anxiety, and amour-propre to extend the young man's compassion.

Rousseau attends to the dangerous potential of all these passions, both in Emile and elsewhere. Earlier in the text, he had described "vile fear" as one of "the most dangerous passions." ${ }^{39}$ When it comes to anxiety about the future, or what he calls "foresight," he describes it as "the true source of all our miseries." ${ }^{40}$ He calls amourpropre "a useful but dangerous instrument" which "rarely does good without evil." ${ }^{11}$ If Emile's education in compassion could have been accomplished with only the assistance of friendship, gratitude, and obligation-tools that Rousseau never describes as dangerous-the project would likely have left out the more dangerous passions. However, as Rousseau makes clear in the sections concerned with Emile's education in compassion, extending this sentiment from one's friends and benefactors ("those whom habit has made dear or necessary to him") to the entire species (including those members who do not have such a "manifest identity" to him) is an arduous process possible "only after having cultivated his nature in countless ways, after many reflections on his own sentiments and on those he observes in others." ${ }^{42}$ Following the cultivation strategy employed by the tutor, the more dangerous passions are used precisely in order to extend Emile's compassion past the artificial distinctions of class.

In the following sections, I show the ways in which Rousseau deploys fear, anxiety, and amour-propre in order to develop compassion strong enough to see past the artificial socioeconomic distinctions in society. In doing so, I also follow Rousseau beyond the strict confines of Emile's moral cultivation project and into his reflections about the ways fear, anxiety, and amour-propre can operate to extend compassion even in the case of less perfectly educated individuals. The three mechanisms I reconstruct Rousseau as proposing are fear of downward social mobility, religious anxiety, and pride.

\footnotetext{
38. Ibid., 731-32, 734-35.

39. Rousseau, Emile, 91-92; and Rousseau, Oeuvres IV, 321 (see note 3 above for both sources).

40. Rousseau, Emile, 82; and Rousseau, Oeuvres IV, 307.

41. Rousseau, Emile, 536; and Rousseau, Oeuvres IV, 24-25.

42. Rousseau, Emile, 223; and Rousseau, Oeuvres IV, 520.
} 


\section{Fear and Anxiety about the Future}

To date, there has been no systematic discussion of the role of fear and anxiety in Rousseau's moral psychology, neither in the particular project of developing compassion nor in the overall moral education project. This is surprising given the important similarities and interactions between fear and anxiety about the future and other dangerous passions such as amour-propre. The operation of all of these passions is carefully restricted during the physical education of Books I-III, then actively used in the sentimental and moral education of Books IV and V. They all represent dangerous passions responsible for human misery while simultaneously carrying redemptive potential for both education and politics. In attending to these dangerous passions together, scholars can get a clearer picture of the complexity of Rousseau's moral education project.

Children, Rousseau contends, are fearful out of both weakness and ignorance. ${ }^{43}$ They fear strange objects, ${ }^{44}$ spiders,${ }^{45}$ and the dark. ${ }^{46}$ Fear is so natural to childhood that "there is no object so worthy of compassion as a fearful child." ${ }^{37}$ Although natural, it is also something to be gradually overcome. For an adult, fear is connected with a number of "fatal" moral ills: "cowardice, pusillanimity, credulousness, terror of death." ${ }^{48}$ The pedagogical approach to fear in Books I-III is therefore to temper and reduce it through experience, accurate perception, and habituation. This, Rousseau stresses, is the opposite of the pedagogical approach employed by others who often make use of fear in order to get children to follow instructions. ${ }^{49}$ If the early approach towards fear is to reduce it, the early approach towards anxiety about the future is to keep it from developing altogether. Children naturally think only of the present. ${ }^{50}$ During this stage of development, Rousseau gives the most extensive diatribes against anxiety for the future, attributing all of human misery to this imaginary extension of the self. ${ }^{51}$ Like the merchant who is content until opening a letter that leads him to despair, men are drawn out of themselves and

43. Rousseau, Emile, 63; and Rousseau, Oeuvres IV, 282 (see note 3 above for both sources).

44. Rousseau, Emile, 63; and Rousseau, Oeuvres IV, 282.

45. Rousseau, Emile, 64; and Rousseau, Oeuvres IV, 282.

46. Rousseau, Emile, 134-37; and Rousseau, Oeuvres IV, 382.

47. Rousseau, Emile, 89; and Rousseau, Oeuvres IV, 316.

48. Rousseau, Emile, 54; and Rousseau, Oeuvres IV, 269.

49. Rousseau, Emile, 91-92; and Rousseau, Oeuvres IV, 321.

50. Rousseau, Emile, 123; and Rousseau, Oeuvres IV, 366.

51. Rousseau, Emile, 83; and Rousseau, Oeuvres IV, 307. 
cease to feel their existence in themselves. ${ }^{52}$ At this stage of development, imaginary extensions of the self are strictly avoided.

Things change during adolescence, where the birth of stronger passions can no longer be forestalled: "Whatever we may do, these passions will be born in spite of us. It is therefore time to change method." 53 Among the changes in method comes a new approach to both fear and anxiety about the future. For a wealthy and wellborn young man to feel compassion for the poor and unfortunate, he must be able to think of their experiences as (at least potentially) his own. Rousseau chose a rich pupil to counteract the especially detrimental education the rich usually receive from their status. ${ }^{54} \mathrm{He}$ explicitly connects the failures of compassion by the upper classes with a lack of fear: "Why are the rich so hard towards the poor? It is because they have no fear [peur] of becoming poor." ${ }^{55}$ Fear and emotions with a family resemblance (anxiety, concern about the future, and awareness of vulnerability) serve to make the pupil feel his shared humanity with the poor and the unfortunate by making him imagine their experiences as his own. Rousseau repeatedly speaks of creating fear: "Unsettle and frighten [effrayez] his imagination with the perils by which every man is constantly surrounded." ${ }^{56}$ This fear ranges in intensity from a generalized concern about one's future to an emotionally powerful and almost paralyzing dread that would lead the young man to seek physical comfort from his friend and tutor: "Let him see around him all these abysses and, hearing you describe them, hold on to you for fear [peur] of falling into them." ${ }^{\text {" W }}$ We can imagine the young man terrified as he comes to understand that "all their ills [of those unfortunate men] are there in the ground beneath his feet." 58

Fear makes real for Emile the possibility that he could experience the same ills as the poor and the unfortunate. He learns that he can never expect his fortune to guard him from hunger, illness, death, poverty, or even slavery. The tutor is to choose from among the numerous examples of men whose socioeconomic status did not protect them from the suffering characteristic of the human condition. Others "from a station higher than his" have fallen even beneath the station of

52. Rousseau, Emile, 83; and Rousseau, Oeuvres IV, 307 (see note 3 above for both sources).

53. Rousseau, Emile, 215; and Rousseau, Oeuvres IV, 494.

54. Rousseau, Emile, 52; and Rousseau, Oeuvres IV, 267.

55. Rousseau, Emile, 224; and Rousseau, Oeuvres IV, 507.

56. Rousseau, Emile, 224; and Rousseau, Oeuvres IV, 508.

57. Rousseau, Emile, 224; and Rousseau, Oeuvres IV, 508.

58. Rousseau, Emile, 224; and Rousseau, Oeuvres IV, 508. 
the poor. ${ }^{59}$ Emile is shown that he has no way of knowing his economic and political future in advance, leading him to be concerned about his fate independent of his wealth and status. He does not even know if he will be alive tomorrow, let alone "whether in a month he will be rich or poor; whether within a year perhaps he will not be rowing under the lash in the galleys of Algiers." ${ }^{\circ 0}$ This final prediction anticipates the story in the unpublished sequel, where Emile is captured and sold as a slave in North Africa. ${ }^{61}$ Although learning that human fate is volatile is important, these facts are insufficiently motivating so long as they do not engage Emile's sentiments, particularly his anxiety about his own future. Even a plan of consistently introducing the young man to examples of human suffering can backfire if Emile does not regard the possible trauma of poverty as his own: "Do not, therefore, accustom your pupil to regard the sufferings of the unfortunate and the labors of the poor from the height of his glory; and do not hope to teach him compassion, if he considers them alien to him." ${ }^{2}$ The point is for the young man to feel what it would be like: "Let him see, let him feel the human calamities."63

Although fear and anxiety play an important role in extending Emile's nascent sensibility across class lines, their use must be carefully deployed. Identifying too closely with the suffering of another-to the point of experiencing it oneself-can actually turn Emile's attention inwards and make him less responsive to others. Rousseau argues that compassion requires either the experience of past suffering or the fear of future suffering, but not the present experience of suffering: "To sympathize with another's misfortune, one doubtless needs to know it, but one does not need to feel it. When one has suffered or fears suffering, one feels compassion for those who suffer; but when one is suffering, one feels compassion only for oneself." 64 Precisely because the adolescent Emile has little past experience with suffering, he would appear insensitive to many of the pains characteristic of the human condition, especially harder to see moral and mental pains ${ }^{65}$ This ignorance turns into compassion "when they begin to feel that there are in human life countless pains

59. Rousseau, Emile, 224; and Rousseau, Oeuvres IV, 508 (see note 3 above for both sources).

60. Rousseau, Emile, 224; and Rousseau, Oeuvres IV, 508.

61. Jean-Jacques Rousseau, "Emile et Sophie, ou les Solitaires," in Rousseau, Oeuvres IV, 881-924 (see note 3 above).

62. Rousseau, Emile, 224; and Rousseau, Oeuvres IV, 507 (see note 3 above for both sources).

63. Rousseau, Emile, 224; and Rousseau, Oeuvres IV, 508.

64. Rousseau, Emile, 229; and Rousseau, Oeuvres IV, 514; emphasis added.

65. Rousseau, Emile, 227; and Rousseau, Oeuvres IV, 511-12. 
they did not know." ${ }^{66}$ This knowledge comes primarily from fear and anxiety rather than actual experience.

Although Emile appears destined to experience both slavery and poverty in his own life, his sentimental education is completed prior to his subjection to these harder tests. The counterfactual would be the young addressee of the "Profession of Faith of the Savoyard Vicar." The "Profession" is part of a long digression within the main text of Emile where Rousseau claims to be transcribing a paper by an unnamed author. This author describes a series of encounters and conversations between himself as a young man and a Vicar from Savoy. In the "Profession," the Vicar explains his beliefs concerning religion, God, and conscience to his young interlocutor. ${ }^{67}$ The young man's early suffering on account of poverty and low social status had nearly destroyed his character and moral capacity. Prior to encountering the Savoyard Vicar, the young man was close to a "moral death." ${ }^{68}$ His poverty had affected his bourgeoning ability to discern good and evil: "the opprobrium to which fortune had reduced the boy stifled every true sentiment of good and evil in him." 69 In addition to the purely moral effects, his poverty and sufferings had also distorted his moral sentiments, leading him to what Rousseau calls "a proud misanthropy" which he describes as "the most difficult to destroy." ${ }^{70}$ Unlike Emile, who understands human suffering without experiencing it too closely and comes to feel compassion for both the poor and the wealthy, the young man of the "Profession" describes himself as feeling "a certain bitterness against the rich and happy of the world, as though they were such at my expense." ${ }^{\text {11 }}$ Instead of fearing their condition, the young man had come to envy it, a sentiment that was particularly difficult to destroy. Rousseau's reflections on the pernicious effects of extreme poverty remain important warnings to making excessive use of actual rather than potential suffering in one's early education: "there is a degree of degradation which takes away life from the soul, and the inner voice cannot make itself heard to someone who thinks only of feeding himself." ${ }^{72}$ Emile is not exposed to these moral risks

66. Rousseau, Emile, 227; and Rousseau, Oeuvres IV, 512 (see note 3 above for both sources).

67. Rousseau, Emile, 266-313; and Rousseau, Oeuvres IV, 565-633. There is an extensive literature discussing the "Profession" and the degree to which it represents Rousseau's genuine views concerning religion and conscience. For an overview, see Jeffrey Macy, "'God Helps Those Who Help Themselves': New Light on the Theological-Political Teaching in Rousseau's 'Profession of Faith of the Savoyard Vicar,'” Polity 24 (1992): 615-32, especially 618-19 n8.

68. Rousseau, Emile, 264; and Rousseau, Oeuvres IV, 562.

69. Rousseau, Emile, 264; and Rousseau, Oeuvres IV, 562.

70. Rousseau, Emile, 265; and Rousseau, Oeuvres IV, 564.

71. Rousseau, Emile, 265; and Rousseau, Oeuvres IV, 564.

72. Rousseau, Emile, 264; and Rousseau, Oeuvres IV, 562. 
associated with poverty, at least not until his sentiments and his moral compass have been developed and tested sufficiently to ensure that the experiences will not change his character. Fear and anxiety about the future therefore substitute for these experiences in order to extend the circle of Emile's affection beyond any artificially created barriers of socioeconomic status.

\section{Fear of Downward Social Mobility and Religious Anxiety}

Rousseau does not limit his analysis of fear and anxiety strictly to the project of educating the protagonist Emile. Within the book, he also gives readers examples of fear and anxiety operating through political institutions and religious doctrine to extend compassion across class lines. The first such example is that of the Turks within the Ottoman Empire. According to Rousseau, the Turkish upper classes were generally more compassionate than the French nobility. ${ }^{73}$ As an explanation, he proposes that "their totally arbitrary government ... renders the greatness and fortune of individuals always precarious and unsteady." 74 This personal vulnerability to "abasement and poverty" as real possibilities within their lifetime, Rousseau claims, had real effects on their compassion towards and treatment of those who are poor and suffering. ${ }^{75}$ To further establish the link he is making, he also adds a footnote claiming that as socioeconomic conditions become more stable, the people become less compassionate. Just as in the case of Emile, the expectation that "each may be tomorrow what the other is today" (rather than the experience of downward mobility itself) helps extend compassion across socioeconomic lines. ${ }^{76}$ Although Rousseau is not proposing exacerbating the arbitrariness of government to foster compassion, he does suggest that making individuals aware of socioeconomic instability can have salutary effects on the morality of the upper classes. In a passage addressed directly to the reader, Rousseau chastises his imagined audience for assuming that the European monarchies will continue to exhibit the previous stability of ranks and socioeconomic status:

You trust in the present order of society without thinking that this order is subject to inevitable revolutions, and it is impossible for you to foresee or prevent the one which may affect your children. The noble become commoners, the rich become poor, the monarch becomes subject. Are the blows

73. Rousseau, Emile, 224; and Rousseau, Oeuvres IV, 507 (see note 3 above for both sources).

74. Rousseau, Emile, 224; and Rousseau, Oeuvres IV, 507.

75. Rousseau, Emile, 224; and Rousseau, Oeuvres IV, 507.

76. Rousseau, Emile, 224; and Rousseau, Oeuvres IV, 507. 
of fate so rare that you can count on being exempted from them? We are approaching a state of crisis and the age of revolutions. ${ }^{77}$

The unanticipated experience of falling from higher status is unlikely to make a man good either for himself or for others. Right before this paragraph, Rousseau gives the example of a "great lord who has become destitute" and an "impoverished rich man," both of whom become contemptible rather than compassionate. ${ }^{78}$ The discussion of compassion by the Turkish upper classes shows that salutary effects come from a general fear and anxiety about the future and not from the actual experience of downward social mobility. Rousseau's address can therefore serve to arouse a similar fear of socioeconomic decline among his well-off readers-a way of motivating them to care about the welfare of the poor in the here and now. ${ }^{79}$

A second example of dangerous passions cultivating compassion on a larger scale concerns religious anxiety. By projecting the expectation of downward social mobility into an imagined existence beyond one's life, anxiety about the afterlife extends the salutary potential of fear in order to motivate concern for the well-being of the lower classes. Rousseau's primary example again turns to the Middle East and the so-called "Pont-Serrho." According to travel reports Rousseau is citing, Muslims and Persians believed that on the final judgment day everyone will be resurrected and subjected to a number of tests to determine their eternal fate. The third and final test would be the crossing of Pont-Serrho, a sacred bridge that extends over the fire of hell. Failure to cross would constitute condemnation to the eternal fires. Believers held that "one will not cross the bridge of hell without having rendered the last penny to those one has oppressed." 80 Because of the strength of this belief, Rousseau claims that elite Persians behaved in considerate ways towards the poor. Out of fear that any one of the poor who have been mistreated during their life can shout "Haro," which would serve as a veto to eternal salvation, all have a powerful incentive to behave compassionately in the here and now. Belief in this bridge that promises a correction of injustices at the end of one's life is likely to prevent those same injustices during the course of life on earth. ${ }^{81}$ By relying on anxiety about the

77. Rousseau, Emile, 194; and Rousseau, Oeuvres IV, 468 (see note 3 above for both sources).

78. Rousseau, Emile, 194; and Rousseau, Oeuvres IV, 468.

79. As Rousseau makes clear throughout Emile, the development of compassion is good both for oneself and for others. This exhortation can therefore be regarded as being for the sake of rich and poor alike.

80. Rousseau, Emile, 314; and Rousseau, Oeuvres IV, 634.

81. Rousseau, Emile, 314; and Rousseau, Oeuvres IV, 635. 
afterlife, Rousseau argues, the Persians gave strong incentives to the rich to act more fairly and compassionately towards the poor.

The importance of fear, anxiety, and religious belief in promoting compassion is a feature that Rousseau identifies in all of the Abrahamic religions. Anxiety about the afterlife along with fear of divine disfavor in the here and now are important emotional tools that can extend compassion across socioeconomic status and promote beneficent actions:

How many works of mercy are the result of the Gospel! Among the Catholics, how many restitutions, how many reparations are caused by the confession! Among us, how many reconciliations and deeds of charity are fostered by the approach of Communion time. How much less greedy usurers were made by the Jubilee of the Hebrews, and how many miseries it prevented! The brotherhood promoted by this law united the whole nation, and not a beggar was to be seen among them. Nor are any seen among the Turks, who have innumerable pious institutions. They are hospitable from religious principle, even toward the enemies of their worship. ${ }^{82}$

This fear of the afterlife leads to compassion through a different route than the fear of poverty experienced by the adolescent Emile. In Emile's case, fear allowed him to imagine the circumstances and experiences of the poor as potentially his own. An initial experience of concern about his own future is followed by a realization that there is less distance between himself and the poor than he might have believed otherwise, leading him to see them as his semblables. In the case of religious anxiety, fear also initially operates on self-interest, getting individuals to care about the suffering of others out of a concern for their own future happiness. ${ }^{83}$ However, religious anxiety does not automatically reveal the underlying similarities between rich and poor in the here and now (although the projected reversal of power in the afterlife could lead to such a realization). Still, in order to respond to the anxiety about the Pont-Serrho, the rich and powerful must actually extend their compassion toward the poor in order to properly scrutinize their interactions. Rousseau suggests that the disappearance of the Pont-Serrho "would put the latter [the rich] very much at their ease and would deliver them from the care of placating these unfortunates," much like the disappearance of fear of downward mobility

82. Rousseau, Emile, 313; and Rousseau, Oeuvres IV, 634 (see note 3 above for both sources).

83. For Rousseau, there is less distance than one might expect between love of self and love of others; see Emile, 235n; and Rousseau, Oeuvres IV, 523n. 
would harden the rich against the poor. ${ }^{84}$ As should be clear from this analysis, the success of this second strategy depends on belief in an afterlife. According to Rousseau, an atheist who reasons would have no cause to extend his concern to others: "let all mankind, if need be, die in suffering and poverty to spare me a moment of pain and hunger." ${ }^{15}$ In this Rousseau would agree with Hume that reason alone could lead one to prefer the destruction of the world to the scratching of one's finger. In this case, as in many others, Rousseau's defense of religion praises its moral and political effects, particularly in the case of the relationship of socioeconomic classes towards one another. ${ }^{86}$

In one of the extended footnotes in Emile, Rousseau weighs in on the contemporaneous debate between faith and reason-specifically, the conversation in eighteenth-century France between the so-called philosophes, advocating a secular philosophy, and the defenders of traditional religion. Rousseau's argument against philosophical skepticism is that it destroys religious principles which serve as affective restraints on class conflict: "Moreover, by overturning, destroying, and trampling on all that men respect, they deprive the afflicted of the last consolation of their misery, and the powerful and the rich of the only brake on their passions." ${ }^{87}$ Skepticism on a mass scale, according to Rousseau, does not offer alternative grounds for compassion across class boundaries. Even if the rich have an obligation to behave compassionately towards the poor as Marks contends, ${ }^{88}$ Rousseau does not think philosophy gives a compelling emotional basis to limit the harsh and self-aggrandizing behavior of the rich. As a challenge to the skeptical philosophers of his time, Rousseau demands: "Stop beating around the bush for a moment, and tell me plainly what you put in the place of Pont-Serrho."

84. Rousseau, Emile, 314; and Rousseau, Oeuvres IV, 635 (see note 3 above for both sources).

85. Rousseau, Emile, 315; and Rousseau, Oeuvres IV, 636 (see note 3 above for both sources).

86. The precise beliefs about God and the afterlife that Rousseau endorses would occupy a much longer essay. While divine benevolence-which Marks identifies with gratitude-is certainly important, so is a sense of divine justice and a corresponding fear and anxiety about the afterlife in cases where one fails to fulfill one's moral duties or follow one's moral sentiments; see his "Discriminating Defense," 732-34 (see note 12 above). For more on the importance to Rousseau's moral system of both divine benevolence and divine justice, see JeanJacques Rousseau, "Letter to Voltaire," in The Discourses and Other Early Political Writings, ed. Victor Gourevitch (Cambridge, U.K.: Cambridge University Press, 1997), 232-46; and Rousseau, Oeuvres IV, 1059-75 (see note 3 above for both sources).

87. Rousseau, Emile, 312; and Rousseau, Oeuvres IV, 632 (see note 3 above for both sources).

88. Marks, "Discriminating Defense," 734-35 (see note 12 above).

89. Rousseau, Emile, 314; and Rousseau, Oeuvres IV, 635 (see note 3 above for both sources). 


\section{Amour-propre}

Amour-propre is a technical term employed by philosophers and intellectuals from the late sixteenth to the early eighteenth centuries. ${ }^{90}$ It can be translated most literally as "self-love," and has been variously rendered as ego, self-esteem, self-regard, pride, etc. ${ }^{91}$ Early scholarship on Rousseau's use of amour-propre drew a sharp contrast between amour de soi-même as a "benign concern for one's self-preservation and well-being" and amour-propre as a "malign concern to stand above other people." ${ }^{\prime 2}$ Revisionist scholarship has challenged this sharp distinction and replaced it with a more complex picture of amour-propre that has benign (even salutary) versions concerned with equal recognition and malign versions concerned with domination and superior status. This literature has generally prioritized the more developed account of amour-propre in Emile rather than the simpler contrast provided in the Discourse on Inequality. ${ }^{93}$ Despite extensive scholarly interest in amour-propre, the precise ways in which it can be used to extend rather than stifle compassion under circumstances of persistent socioeconomic inequality have remained underspecified.

Marks's defense of compassion mentions amour-propre only once as a force working against compassion, ${ }^{94}$ while discussions that do acknowledge the contribution of amour-propre are generally critical of compassion and its political consequences. ${ }^{95}$ This section's contribution is to integrate amour-propre with the other dangerous passions that Rousseau uses in his project of extending compassion across socioeconomic barriers and to further specify the education strategy employed. Amour-propre is a useful ally precisely in making socioeconomic inequality less salient for compassion and can work as a first step in extending compassion towards those of different (especially higher) socioeconomic status. Critics are right

90. For a discussion of its use prior to Rousseau, see, for example, Michael L. McLendon, "Rousseau, Amour-Propre, and Intellectual Celebrity," Lournal of Politics 71 (2009): 506-19, at 506.

91. Scholars most commonly leave the term untranslated to reflect its contested English meaning.

92. N. J. H. Dent and Timothy O’Hagan, "Rousseau on Amour-Propre," Aristotelian Society 72 (1998): 57-73, at 57.

93. For extended discussions of the more complex conception, see Dent and O'Hagan, "Rousseau on Amour-Propre" (see previous note); Neuhouser, Rousseau's Theodicy of Self-Love (see note 7 above); also see N. J. H. Dent, Rousseau: His Psychological, Social and Political Theory (New York: Basil Blackwell, 1988); Timothy O’Hagan, Rousseau (London: Routledge, 1999); and Laurence D. Cooper, "Rousseau on Self-Love: What We've Learned, What We Might Have Learned," Review of Politics 60 (1998): 661-83. For an argument against this revisionist turn, see Avner Inbar, "The Rehabilitation of Amour-Propre," History of Political Thought 40 (2019): 458-83.

94. Marks, "Discriminating Defense," 737 (see note 12 above).

95. Boyd, "Pity's Pathologies," 534 (see note 9 above); and Orwin, "Discovery of Political Compassion," 306 (see note 2 above). 
to note its potential for substituting other forms of difference for wealth and status, a risk that Rousseau himself acknowledges and actively addresses in the second step of deflating the potentially inflamed amour-propre through experiences of failure.

Emile's education in compassion is bound up with his amour-propre, if only because compassion is "the first relative sentiment which touches the human heart according to the order of nature," and amour-propre is intimately connected with the "relative I." 96 To the extent that amour-propre is involved with any comparisons, at least a benign form of amour-propre is involved from the first instances of compassion: "the first glance he casts on his fellows leads him to compare himself with them." ${ }^{\prime 97}$ However, Rousseau only begins to rely on amour-propre once he has to introduce Emile to the artificial differences between individuals that appear within society. This is the stage after the first discussion of fear and anxiety and the way they can extend the young man's compassion towards those from a lower socioeconomic status: "To guide him in this research, we must now show him men by means of their differences, having already showed him men by means of the accidents common to the species. Now comes the measurement of natural and civil inequality and the picture of the whole social order." ${ }^{\prime 8}$

The form of amour-propre employed for this part of the project is not the transformed desire for equal recognition described by Neuhouser, ${ }^{99}$ but rather "the desire to be in the first position." ${ }^{100}$ The mutual interdependence of amour-propre and compassion becomes most salient when it comes to showing Emile the socioeconomic inequalities that are inevitable in civil society and impossible in the state of nature. ${ }^{101}$ Neuhouser is right to argue that for Rousseau economic inequality is linked to unhappiness only when wealth is widely regarded as a source of recognition and esteem. ${ }^{102}$ Although Neuhouser expects this further assumption to be a near universal feature of commercial societies, Rousseau's project of extending compassion through amour-propre, fear, and anxiety allows Emile to avoid this source of unhappiness even in an unequal society. However, as this section points out, amour-propre extends compassion at the risk of replacing distinctions based on class with distinctions based on moral excellence. Counteracting this emerging

96. Rousseau, Emile, 222, 243; and Rousseau, Oeuvres IV, 505, 534 (see note 3 above for both sources).

97. Rousseau, Emile, 235; and Rousseau, Oeuvres IV, 523.

98. Rousseau, Emile, 235; and Rousseau, Oeuvres IV, 524.

99. Neuhouser, Rousseau's Theodicy of Self-Love, 218-64 (see note 7 above).

100. Rousseau, Emile, 235; and Rousseau, Oeuvres IV, 523.

101. Rousseau, Emile, 236; and Rousseau, Oeuvres IV, 524.

102. Neuhouser, "Rousseau's Critique," 206 (see note 13 above). 
contraction of compassion would require alternative methods that rely on actual experience of suffering rather than fear and anxiety.

This portion of Emile's education is almost entirely carried out by means of studying history. ${ }^{103}$ The discussion begins and ends with amour-propre, which Rousseau refers to as a "useful and dangerous instrument."104 The overall goal of this section is to incline Emile's character towards commiseration and its attendant sweet passions rather than envy and its attendant bitter ones. ${ }^{105}$ This means that one must feel compassion rather than envy even around those who are wealthier or better born. Reaching that goal requires an assessment of the relative happiness of various socioeconomic stations, obtained primarily through the reading of ancient biographies such as Plutarch's. ${ }^{106}$ In the first maxim of compassion, Rousseau explicitly spelled out the way to address the failures of compassion for one's socioeconomic superiors, connecting the remedy to fear: "It follows, therefore, that, in order to incline a young man to humanity, far from making him admire the brilliant lot of others, one must show him the sad sides of that lot, one must make him fear [craindre] it." ${ }^{107}$ Fear is not only useful in allowing Emile to imagine himself experiencing the suffering of poverty, but also in imagining the experience of acquiring wealth and status as itself a form of suffering. This fear of riches and exalted sociopolitical status is something that Rousseau describes himself as sharing. In a thought experiment at the end of Book IV, Rousseau considers what effect wealth would have on his character and connects it to the destruction of compassion. ${ }^{108} \mathrm{He}$ confesses his terror at being placed in position of power precisely because of the risk that he would become cruel towards others:

I have a hundred times thought with terror that if I had the misfortune today of filling a particular position in a certain country, tomorrow I would almost inevitably be a tyrant, an extortionist, a destroyer of the people, and a source of harm to the prince; due to my situation I would be an enemy of all humanity, of all equity, of every sort of virtue. ${ }^{109}$

103. On the advantages of choosing history for the education of compassion, see Schaeffer, "Education, Freedom, Judgment," 94-96 (see note 5 above)

104. Rousseau, Emile, 244; and Rousseau, Oeuvres IV, 536 (see note 3 above for both sources).

105. Rousseau, Emile, 235; and Rousseau, Oeuvres IV, 523.

106. Rousseau, Emile, 236; and Rousseau, Oeuvres IV, 525.

107. Rousseau, Emile, 223; and Rousseau, Oeuvres IV, 507.

108. Rousseau, Emile, 345; and Rousseau, Oeuvres IV, 678.

109. Rousseau, Emile, 345; and Rousseau, Oeuvres IV, 678. 
The implication is that the moral corruption that comes with an elevated status would take a psychological toll, whether through the pangs of conscience or through the ongoing anxiety of worldly or divine retribution. Not only does the experience of fear and anxiety about his future allow Emile to feel compassion for those who are poor and unfortunate, but it allows him to recognize fear and anxiety among the wealthy and powerful. By reflecting on these experiences, Emile will eventually come to see that not only can wealth and status not protect him from the suffering characteristic of the human condition, but that these can themselves be a source of suffering. By attributing suffering to the higher socioeconomic ranks, Emile's history lessons give him reasons to feel compassion for the upper classes that are independent of their fall from status. Rousseau is well aware that not all the rich and powerful lose their wealth and status and Emile must be able to feel compassion rather than envy even for those who retain all of the apparent advantages of fortune:

All conquerors have not been killed; all usurpers have not failed in their enterprises; several will appear happy to minds biased by vulgar opinions. But he who does not stop at appearances but judges the happiness of men only by the condition of their hearts will see their miseries in their very successes; he will see their desires and their gnawing cares extend and increase with their fortune; he will see them getting out of breath in advancing without ever reaching their goals. ${ }^{110}$

Amour-propre drives Emile's desire to compare himself widely with individuals of different socioeconomic status. In learning to fear both poverty and wealth, his amour-propre is subsequently gratified without seeking to acquire a higher socioeconomic status himself. The combination of these sentiments leads Emile to end this portion of his education universally compassionate towards all different ranks and occupations: "He feels compassion for these miserable kings, slaves of all that obey them. He feels compassion for these false wise men, chained to their vain reputations. He feels compassion for these rich fools, martyrs to their display. . .." ${ }^{111}$ Comfortable within his position, the young man can use his superfluous emotional and material resources to indulge his expansive compassion. ${ }^{112}$ So

110. Rousseau, Emile, 242; and Rousseau, Oeuvres IV, 533 (see note 3 above for both sources).

111. Rousseau, Emile, 244; and Rousseau, Oeuvres IV, 536 (see note 3 above for both sources).

112. Rousseau does not fully explain why Emile does not decide to help the rich as well as the poor. His generalization of the sentiment might help him prioritize the greater or more innocent suffering of the poor. Alternatively, Emile might not have the authority or power to effectively assist them. 
long as his emotional inclination towards the wealthy and powerful is compassionate, there would be no room for envy or emulation. ${ }^{113}$ It would be as unreasonable for Emile to pursue wealth and power as it would be for him to pursue disease and dire poverty. If compassion for those from a lower socioeconomic status gives Emile opportunities for active benevolence, compassion for those from a higher socioeconomic status is primarily good for him and his own healthy moral development.

The problem with this entanglement of amour-propre, however, is that it risks replacing socioeconomic superiority with moral superiority as a new barrier to compassion. This may be why this step in Emile's education is described as both difficult and dangerous. ${ }^{114}$ If Emile were to see himself as exempt from the sufferings of both the rich and the poor, he would no longer feel compassion for either: "A young man is hardened and takes pleasure at seeing a sensitive being tormented when a reflection of vanity makes him regard himself as exempt from the same pains as a result of his wisdom or his superiority." ${ }^{115}$ As Emile's education in sentiments begins to include notions of morality and virtue, he risks finding a new source of comfort. Instead of relying on wealth and status to protect him from suffering, Emile may come to believe that his moral superiority will preserve him from sharing in the suffering of others. This would turn his developing compassion into a sterile and hierarchical pity that borders on schadenfreude. ${ }^{116}$

If compassion becomes this form of condescending pride, Rousseau claims that the positive parts of the project are at risk of being overwhelmed by the negatives, making it hard to see the advantage of the education in compassion over the class prejudices he would have acquired without the extensive education: "I do not know whether I would not prefer the illusion of the prejudices to that of pride." ${ }^{117}$ However, to avoid this second outcome, Rousseau turns to a different strategy in order to make Emile feel that he is subject to the same vicissitudes of fortune as others. ${ }^{118}$ In this case, the young man must not only fear the possibility of suffering, but he must actually be exposed to "all the accidents that can prove to him that he is no wiser than they are."119 Not only would he experience the associated humiliation and shame of being "flattered, fleeced and robbed," but his tutor will treat him

113. There would subsequently also be no room for the political violence feared by moral philosophers worried about the strength of compassion.

114. Rousseau, Emile, 237; and Rousseau, Oeuvres IV, 526 (see note 3 above for both sources).

115. Rousseau, Emile, 251; and Rousseau, Oeuvres IV, 545.

116. Rousseau, Emile, 245; and Rousseau, Oeuvres IV, 536-37.

117. Rousseau, Emile, 245; and Rousseau, Oeuvres IV, 537.

118. Rousseau, Emile, 245; and Rousseau, Oeuvres IV, 537.

119. Rousseau, Emile, 245; and Rousseau, Oeuvres IV, 537. 
to the same compassion that he had shown others. ${ }^{120}$ This would cut off the prideful dimension as he experienced his own vulnerability and felt himself the object of a similar compassion as the one he felt towards others. ${ }^{121}$ After these experiences with suffering that comes not only from accident but also partly from moral fault, Emile might finally read La Fontaine's fables and adjust his attitude to the "games of Fortune" to one of compassion towards others and satisfaction with his own lot. ${ }^{122}$

It is not entirely clear in the text that Emile himself has to go through the path of recovery from pride. In discussing those who think themselves too wise or superior to feel compassion for others, Rousseau claims that "he who has been protected against this turn of mind could not fall into the vice which is its work." ${ }^{23}$ The example of the young man to whom the "Profession of Faith" is addressed provides an alternative example of how amour-propre would be used in the process of extending compassion across socioeconomic lines. That young man's experience with class distinctions had left him lacking in self-esteem and incapable of compassion towards those from a different socioeconomic class. The first step for the Savoyard Vicar was therefore to arouse his amour-propre in order to halt the young man's atrophy of morality and moral sentiments. ${ }^{124}$ This first step in the comparison was insufficient to lead to compassion: "the amour-propre my mentor tried to awaken in me, by leading me to pride, rendered men even more vile in my eyes and succeeded only in adding contempt to my hatred for them." ${ }^{125}$ Instead of combatting amour-propre, however, the Vicar took advantage of the comparative impulse to show the young man the suffering present among the elites as well as the poor. ${ }^{126}$ In getting him to identify wealth and status with suffering, the Vicar could free the young man of his misanthropy and inferiority complex. And in order to avoid the second step of pride out of a sense of moral superiority, he followed a similar path of making the young man be "moved by compassion for human weakness by the profound sentiment of his own." 127 Although Rousseau does not fully expand on the strategies employed by the Vicar, it is worth noting that the story of the Vicar recapitulates the previous lessons from the use of amour-propre in order to extend compassion beyond distinctions of socioeconomic status.

120. Rousseau, Emile, 246; and Rousseau, Oeuvres IV, 538 (see note 3 above for both sources).

121. Rousseau, Emile, 247; and Rousseau, Oeuvres IV, 540.

122. Rousseau, Emile, 249; and Rousseau, Oeuvres IV, 542.

123. Rousseau, Emile, 251; and Rousseau, Oeuvres IV, 545.

124. Rousseau, Emile, 264; and Rousseau, Oeuvres IV, 562.

125. Rousseau, Emile, 265; and Rousseau, Oeuvres IV, 564.

126. Rousseau, Emile, 265; and Rousseau, Oeuvres IV, 564.

127. Rousseau, Emile, 265; and Rousseau, Oeuvres IV, 564. 
When considered in conjunction with fear and anxiety, amour-propre allows Emile to establish a certain form of equality based on common suffering even in the face of pervasive forms of socioeconomic inequality. Emile's conception of suffering is extended beyond "cries and tears." ${ }^{128}$ The pain of broken limbs and emaciated bodies are easy to see and understand. It is the inner suffering with a moral cause that is only revealed by subtle signs difficult to identify. Rousseau describes those who are incapable of understanding "moral suffering" and the "ills of the soul" as potentially lacking not only developed compassion but a range of other sentiments, including justice. ${ }^{129}$ By showing Emile the actual universality of suffering, physical as well as moral, hidden underneath the artificial distinctions of wealth and status, the tutor allows him to achieve the fragile equilibrium which can be described as Rousseau's core principle: believing that men are naturally good, but that society corrupts them. ${ }^{130}$

\section{Emile as a Model of Compassionate Citizenship}

Rousseau's Emile shows the difficulty of forming a young man who is good both for himself and for others within a society characterized by persistent socioeconomic inequalities. In describing the psychological strain on both rich and poor created by such inequalities, Rousseau's project in Emile has a critical edge, showing the costs of living in society and the possibly forbidding difficulty of cultivating compassion under these conditions. ${ }^{131}$ As this article argues, however, the project is also constructive, ${ }^{132}$ providing a model for educating a good man who can be a good husband and even a good citizen. ${ }^{133}$ Many Rousseau scholars have criticized Emile

128. Rousseau, Emile, 227; and Rousseau, Oeuvres IV, 511 (see note 3 above for both sources).

129. Rousseau, Emile, 227; and Rousseau, Oeuvres IV, 511-12 (see note 3 above for both sources).

130. Rousseau, Emile, 237; and Rousseau, Oeuvres IV, 525 (see note 3 above for both sources).

131. Shklar and others have interpreted Rousseau's frequent comments about the difficulty of reform as a sign of his utopianism; see Judith Shklar, Men and Citizens: A Study of Rousseau's Social Theory (Cambridge, U.K.: Cambridge University Press, 1969). Without denying Rousseau's many pessimistic moments, Emile's epigraph states that "we are sick with evils that can be cured" and the preface suggests that his project for moral cultivation is possible in principle anywhere; see Rousseau, Emile, 35; and Rousseau, Oeuvres IV, 243 (see note 3 above for both sources).

132. Rousselière correctly notes that Emile's education represents an alternative model of a man who can be free even in commercial society. However, her account is incomplete without considering the role of moral sentiments, particularly compassion, as part of the educational solution to economic inequality; see her "Rousseau on Freedom" (see note 6 above).

133. Although some have argued that Emile is a fundamentally anti-political treatise concerned with raising a man rather than a citizen, there are numerous textual reasons to read it as a different model of citizenship-one appropriate under the non-ideal conditions of a society characterized by 
for being compassionate in a self-serving manner, failing to translate his identification with the poor into either active benevolence or political action in service of the poor. ${ }^{134}$ If Emile is meant to be a model for the education of a well-born, wealthy young man who is capable of compassion, what are the consequences of this compassion in the social and political realm? This section addresses two primary issues about the political potential of compassion: its political efficacy and its scalability. In doing so, it reveals a model of compassionate citizenship that relies on building social capital in one's neighborhood rather than attempting political change at the national level.

The first thing to note is that Rousseau considers it a significant accomplishment to avoid causing harm under unjust political institutions, particularly for those who are members of the upper class. Rousseau claims that laws in every country "favor the strong against the weak and those who have against those who have not." ${ }^{135}$ In Book V, where Emile is assigned the task of choosing a government under which he and his future wife can live tranquilly, he learns about the harm that the rich do to the poor through rent-seeking, expropriation, excessive taxation, and violence. When Emile acquires land for a family home, he can expect to pay off "administrators, their judges, priests, powerful neighbors, and rascals of every kind, who are always ready to torment you if you neglect them." ${ }^{136}$ He must protect himself from the wealthy who use the law to take advantage of the poor through excessive taxation ("boundless taxes that would devour the fruit of your efforts") and expensive legal procedures ("endless litigation that would consume your estate"). ${ }^{137}$ A rich and powerful neighbor will often find a way to expropriate his poorer neighbors for expensive pastimes such as hunting ${ }^{138}$ or commercial pursuits: "can you be sure that he will not find the means, under some pretext, to invade your inheritance, in order to round off his own, or that you will not see-perhaps tomorrow-all

inequality. In arguing for this reading, this article agrees with Kelly, who describes Emile's citizenship as an anti-heroic model of citizenship as opposed to the Spartan model of the Social Contract or the literary model of citizenship Rousseau himself instantiates; see Kelly, Rousseau as Author, 95-98 (see note 8 above).

134. Boyd, "Pity's Pathologies," 525 (see note 13 above); and Orwin, "Discovery of Political Compassion," 302 (see note 2 above).

135. Rousseau, Emile, 236n; and Rousseau, Oeuvres IV, 524 (see note 3 above for both sources).

136. Rousseau, Emile, 457; and Rousseau, Oeuvres IV, 835.

137. Rousseau, Emile, 457; and Rousseau, Oeuvres IV, 835.

138. Rousseau describes the connection between wealth and harming one's neighbors in a thought experiment in Emile, 352; and Rousseau, Oeuvres IV, 688. 
your resources absorbed into a large highway?"139 Finally, the rich often destroy the marriages of peasants by corrupting their wives and daughters. ${ }^{140}$ Rousseau repeatedly emphasizes that if his pupil had been part of the ruling elite, the education received would lead him to abdicate his position. ${ }^{141}$ All of these occupations carry the risk of causing harm, even while attempting to do good: "If we were kings and were beneficent, we would do countless real evils without knowing it for the sake of an apparent good that we believed we were doing." 142 Instead of attempting to control the levers of power, Emile concentrates his affection towards his community, avoiding the danger of the philosopher who "loves the Tartars so as to be spared having to love his neighbors." ${ }^{143}$

The second response to the concern about the limited impact of Emile's compassion is that Emile, his wife, and their friends and family are responsible for numerous acts of benevolence in their neighborhood. For every vice of the wealthy that imposes costs on their neighbors, Emile and Sophie display the opposite virtue and actively contribute to the well-being of the poorest and most vulnerable members of their village. Instead of seeking to extend their property at the expense of their neighbors, Emile and his wife are satisfied with a small dwelling while assisting their poor neighbors in improving their homes, settling their debts, and becoming self-sufficient. From the beginning of his courtship of Sophie, Emile and the tutor perform an impressive list of good deeds in this poor neighborhood: introducing

139. Rousseau, Emile, 457; and Rousseau, Oeuvres IV, 835 (see note 3 above for both sources).

140. See Rousseau, Emile, 349-50; and Rousseau, Oeuvres IV, 683-85. These passages include a discussion of how the rich pay for sexual favors or otherwise use their wealth in order to seduce women who are disgusted by their appearance.

141. Rousseau, Emile, 264, 50; and Rousseau, Oeuvres IV, 849, 467.

142. Rousseau, Emile, 467; and Rousseau, Oeuvres IV, 849. Precisely because society puts men in contradiction with one another, Rousseau argues that it is more difficult to do good without doing harm rather than to do good simply; see Emile, 105; and Oeuvres IV, 340. Properly cultivated compassion, therefore, must be attuned to the demands of justice; see Emile, 253; and Oeuvres IV, 548. Although a full examination of the relationship of compassion to justice is beyond the scope of the paper, it shows the difficulties of the project as Rousseau conceives of it; see Emile, 105; and Oeuvres IV, 340.

143. Rousseau, Emile, 39; and Rousseau, Oeuvres IV, 249 (see note 3 above for both sources). Although Book V of Emile is focused on the protagonist's ability to be a good neighbor and citizen in his country of birth, the unfinished sequel actually shows Emile acting compassionately towards fellow slaves in Algiers; see Rousseau, "Emile et Sophie," 921-24 (see note 3 above). This indicates that his compassion is capable of extending to individuals of different nationalities and potentially even of different races. The discussion of what the experience of slavery can teach Emile about extending his compassion to Africans captured and sold into slavery during the eighteenth century would occupy another full article. 


\section{4 | Compassion's More Dangerous Allies}

new farming technology, ${ }^{144}$ assisting a poor man in repairing his home,${ }^{145}$ helping to clear land that the impoverished owner abandoned, ${ }^{146}$ gifting poor neighbors livestock, ${ }^{147}$ serving as an arbitrator in local disputes. ${ }^{148}$ Instead of representing a pernicious form of gentrification, he and Sophie therefore promote sustainable development that benefits the community and reduces the socioeconomic inequalities among its members. While the rich usually use their legal knowledge to aggrandize themselves and exploit the poor, Emile takes the side of the weak against the strong and counsels the young. ${ }^{149}$ Rousseau recommends the active exercise of social virtues, particularly when it comes to using one's knowledge and skill to defend the vulnerable against the rapaciousness of the rich:

How many of the oppressed who would never have been heard will obtain justice when he asks for it on their behalf with that intrepid firmness given by the practice of virtue, when he forces the doors of the noble and the rich, when he goes, if necessary, to the foot of the throne to make heard the voice of the unfortunates to whom all access is closed by their poverty and who are prevented by fear of being punished for the ills done to them if they even dare to complain? ${ }^{150}$

Finally, while rich neighbors usually corrupt the morals of the young and destroy the domestic tranquility of the poor, Emile helps two young people who wish to get married, ${ }^{151}$ assists a drunk peasant and his wife who is in labor, ${ }^{152}$ and provides medical care and consolation to those who lose their loved ones. ${ }^{153}$ Not only do the young man and his wife actively refrain from the biggest harms the rich cause to their neighbors, but their actively compassionate benevolence transforms

144. Rousseau, Emile, 435; and Rousseau, Oeuvres IV, 804 (see note 3 above for both sources).

145. Rousseau, Emile, 435; and Rousseau, Oeuvres IV, 805.

146. Rousseau, Emile, 435; and Rousseau, Oeuvres IV, 805.

147. Rousseau, Emile, 435; and Rousseau, Oeuvres IV, 805.

148. Rousseau, Emile, 435; and Rousseau, Oeuvres IV, 805.

149. Rousseau, Emile, 436; and Rousseau, Oeuvres IV, 805. Because the young man is not knowledgeable or mature enough to pursue legislative reform, he will not attempt to meddle in public affairs directly or engage in the competition for political office; see Rousseau, Emile, 250; and Rousseau, Oeuvres IV, 544. His models in the youthful pursuit of justice are "those illustrious Romans who, before being admitted to public offices, spent their youth in prosecuting crime and defending innocence, without any other interest than in instructing themselves in serving justice and protecting good morals"; see Rousseau, Emile, 250; and Rousseau, Oeuvres IV, 544.

150. Rousseau, Emile, 250; and Rousseau, Oeuvres IV, 544.

151. Rousseau, Emile, 436; and Rousseau, Oeuvres IV, 805.

152. Rousseau, Emile, 440; and Rousseau, Oeuvres IV, 811-12.

153. Rousseau, Emile, 436; and Rousseau, Oeuvres IV, 805. 
the people around them: "I am moved by contemplating how many benefactions Emile and Sophie can spread around them from their simple retreat, and how much they can vivify the country and reanimate the extinguished zeal of the unfortunate village folk." 154 Through their positive presence and compassionate care for each other and their neighbors, the young couple are able to provide the conditions for a happier way of life for their neighbors, regardless of their social class, and to limit the development of oppressive status differentials among them. Although exploring this model of citizenship fully is beyond the scope of this paper, it is worth noting the ways in which this description anticipates the model of democratic citizenship at the local level described by de Tocqueville in his Democracy in America. ${ }^{155}$

The second criticism about the political consequences of compassion concerns the feasibility of scaling up the educational methods of Emile. In noting Rousseau's analysis of inequality, Williams directs readers to the ambitious reforms Rousseau himself proposed to "forestall the ever-widening inequality of fortunes," including substantial reforms of the currency, the tax system, and property rights. ${ }^{156}$ Although highly demanding even for Rousseau's time, these methods would at least address the problem of inequality at its root. By comparison, one may worry that, even if Emile and Sophie constitute model neighbors who refrain from oppression and spread well-being in their neighborhood, the educational strategies in the text do not scale up sufficiently to produce widespread changes. Although Emile relies primarily on education rather than political or economic reform, there is no reason to consider Rousseau's educational reforms as less fundamental or impactful than his institutional solutions. ${ }^{157}$ My contention is that Rousseau regarded his proposed educational reforms as scalable through their substantial appeal to an elite readership

154. Rousseau, Emile, 474; and Rousseau, Oeuvres IV, 859 (see note 3 above for both sources).

155. Alexis de Tocqueville, Democracy in America, ed. Harvey C. Mansfield, trans. Delba Winthrop (Chicago: University of Chicago Press, 2000), 45-52, 165-86, 535-40, 558-605.

156. Williams, "Forestalling," 27-37 (see note 15 above); see also Frederick Neuhouser, Rousseau's Critique of Inequality: Reconstructing the Second Discourse (Cambridge, U.K.: Cambridge University Press, 2014). Neuhouser takes Rousseau's practical suggestions to be utopian and dismisses them (see $207 \mathrm{n} 42$ ).

157. In a previous article, I have argued that the two primary models for managing pluralism in Rousseau's Social Contract and his later political writings are the Spartan model of fostering consensus through an encompassing public education system and the Roman model of managing pluralism through institutional design. For further discussion, see Alexandra Oprea, "Pluralism and the General Will: The Roman and Spartan Models in Rousseau's Social Contract," Review of Politics 81 (2019): 573-96. 
whose children were most at risk of failing to develop compassion across socioeconomic lines.

Much like Locke's Some Thoughts Concerning Education, Rousseau addresses Emile to parents rather than statesmen: "It is to you that I address myself, tender and foresighted mother, who are capable of keeping the nascent shrub away from the highway and securing it from the impact of human opinions!" ${ }^{158}$ Emile is in part an attempt at persuasion addressed to upper class mothers who control the education of their children, a private solution as opposed to a public education program imposed through the state. ${ }^{159}$ If this is at least a part of Rousseau's project, then the usual accusation that his notion of compassion is selfish and benefits the compassionate individual turns out to be most beneficial. Mothers, Rousseau tells us, are motivated by wanting their children to be happy in the moment and throughout their lives. ${ }^{160}$ Emile is not meant to be either a brother of charity constantly occupied with relieving physical suffering ${ }^{161}$ or a political operative risking his life or virtue to change the system. ${ }^{162}$ The picture of domestic bliss, freedom, happiness, and independence Rousseau paints for the compassionate young man helps demonstrate the viability of an education in compassion for parents who might have feared that compassion comes at a steep cost to one's happiness. As Rousseau never tires of telling his readers in Emile, even seemingly minor reforms in the behavior of mothers and in early childhood education can create large-scale social change. Referring to breastfeeding children, for example, he claims: "Thus, from the correction of this single abuse would soon result a general reform; nature would soon have reclaimed all its rights." ${ }^{\prime 63}$ By persuading upper class parents to educate children in compassion, Rousseau's proposal can foster democratic citizens with similar community-level impact as Emile and Sophie.

158. John Locke, "Some Thoughts Concerning Education," in Some Thoughts Concerning Education and Of the Conduct of the Understanding, ed. Ruth Grant and Nathan Tarcov (Indianapolis, Ind.: Hackett, (1996), 1-162. See also Rousseau, Emile, 37-38; and Rousseau, Oeuvres IV, 245-46 (see note 3 above for both sources).

159. Note Rousseau's strong emphasis on the role of mothers in the case of nursing their children; see Rousseau, Emile, 46; and Rousseau, Oeuvres IV, 257. To the extent that Rousseau expected (at least some) mothers to educate their children in compassion, the risks of arrogance and inflamed amour-propre would also be likely to be less pronounced than under an all-wise tutor.

160. Rousseau, Emile, 37-38n; and Rousseau, Oeuvres IV, 246n.

161. Rousseau, Emile, 231; and Rousseau, Oeuvres IV, 517.

162. Rousseau, Emile, 250; and Rousseau, Oeuvres IV, 544.

163. Rousseau, Emile, 46; and Rousseau, Oeuvres IV, 257. 


\section{Conclusion: The Politics of Compassion Beyond Emile}

Rousseau is timely in reminding us that compassion is often weak and limited to one's in-group. Overcoming the artificial distinctions created by socioeconomic inequalities is a profoundly difficult task, both personally and politically. Although a full account of the role of compassion in contemporary politics goes beyond the scope of this particular paper, I conclude by considering research in psychology and political science that lends at least prima facie plausibility to some of Rousseau's claims about the contributions of fear of downward social mobility, religious anxiety, and pride to cultivating compassion in unequal societies.

For many observers of Western politics, recent years have displayed a concerning turn toward a politics of resentment, suspicion, and authoritarian populism with decreased support for the welfare state or redistributive policies. ${ }^{164}$ Some have attributed this turn to economic anxieties, particularly for middle class white men. ${ }^{165}$ However, Alt and Iverson have noted that labor market segmentation also leads to less support for redistributive policies: if risks are concentrated among lowskilled laborers, then the middle classes may no longer fear economic downturns because higher-skilled labor is not threatened by the same risks. ${ }^{166}$ Contrary to the expectation that members of the middle class in the United States have weakened their support for redistribution for fear of losing their economic status, their research suggests that it may actually be lack of fear of downward social mobility that erodes their compassion. This explanation fits with Rousseau's diagnosis of the hardness of the (relatively) rich for the poor.

Of course, the turn towards right-wing populism in the West is a recent phenomenon in need of further investigation. Even if the economic dimension is not properly captured by a fear of downward social mobility, it is entirely possible that a different phenomenon is in play when it comes to gender, race, and sexual identity.

164. Katherine J. Cramer, The Politics of Resentment: Rural Consciousness in Wisconsin and the Rise of Scott Walker (Chicago: University of Chicago Press, 2016); Francis Fukuyama, Identity: The Demand for Dignity and the Politics of Resentment (New York: Farrar, Straus, and Giroux, 2018); and Martha Nussbaum, The Monarchy of Fear: A Philosopher Looks at Our Political Crisis (New York: Simon \& Schuster, 2018).

165. Jed Kolko, "Trump was Stronger where the Economy is Weaker," FiveThirtyEight, November 10, 2016, at https://fivethirtyeight.com/features/trump-was-stronger-where-the-economy -is-weaker/.

166. James Alt and Torben Iversen, "Inequality, Labor Market Segmentation, and Preferences for Redistribution," American Journal of Political Science 61 (2017): 21-36. This is particularly problematic when low-skilled laborers are systematically different from middle and upper classes in terms of race, ethnicity, and national origin. 
Many in the media have argued that white heterosexual males have experienced a recent decline in social status, a decline that can trigger a protective in-group oriented response. ${ }^{167}$ An advantage of Rousseau's discussion of compassion is that it can simultaneously account for the negative consequences of actual downward social mobility on compassion while holding out the promise that past experience with downward social mobility and anxiety about future downward mobility can actually extend compassion. Recent work in political science suggests a positive relationship between past experiences with downward social mobility and support for redistributive policies that assist the poor. ${ }^{168}$ For now, all we can say for sure is that empirical evidence lends some plausibility to Rousseau's use of fear and anxiety as compassion's more dangerous allies.

If fear of downward social mobility can motivate the rich to adopt a compassionate orientation towards the poor, Rousseau also argues that amour-propre or pride can have a positive effect on the ability of lower-status individuals to experience compassion towards higher-status individuals. There is evidence to suggest pride can reduce the perceived difference between higher status individuals and oneself. Across three studies, Oveis, Horberg, and Keltner found that individuals experiencing pride perceive themselves as more similar to individuals in groups perceived to be "strong." ${ }^{169}$ Given that self-other similarity has been widely shown to contribute to pro-social behavior, ${ }^{170}$ these findings suggest a higher willingness to assist or otherwise behave compassionately towards members of high-status groups. In a different study, Ashton-James and Tracy have found that authentic pride (associated with self-confidence and accomplishment) can lead to positive attitudes towards stigmatized individuals, partly through the mediation of empathic

167. Niraj Chokshi, “Trump Voters Driven by Fear of Losing Status, Not Economic Anxiety, Study Finds," New York Times, April 24, 2018, at https://www.nytimes.com/2018/04/24/us/poli tics/trump-economic-anxiety.html; and Diana C. Mutz, "Status Threat, Not Economic Hardship, Explains the 2016 Presidential Vote," Proceedings of the National Academy of Sciences 115 (2018): 4330-39.

168. Andrew Dabalen, R.A. Parinduri, and Saumik Paul, "The Effects of the Intensity, Timing, and Persistence of Personal History of Mobility on Support for Redistribution in Transition Countries," Economics of Transition 23 (2015): 565-95; and Elvire Guillaud, "Preferences for Redistribution: An Empirical Analysis over 33 Countries," Lournal of Economic Inequality 11 (2013): 57-78.

169. Christopher Oveis, E. J. Horberg, and Dacher J. Keltner, "Compassion, Pride, and Social Intuitions of Self-Other Similarity," Lournal of Personality and Social Psychology 98 (2010): 618-30. At the same time, pride increases the perceived distance between lower-status individuals and oneself.

170. See ibid., 619-20, for a review of the evidence connecting self-other similarity and prosocial action. 
concern for the out-group. However, the same study found the opposite effect in the case of hubristic pride (associated with arrogance and self-aggrandizement), suggesting that pride is indeed a dangerous tool to use in order to extend compassion. ${ }^{171}$ Social movements representing historically oppressed or marginalized communities have often resorted to a language of "pride" to refer to their individual and group identities. Although it is beyond the scope of this paper to investigate these social movements, there is prima facie plausibility to using pride as a way to mitigate the effects of lower socioeconomic status and eventually foster a more compassionate society.

Similar findings concern the role of religious anxiety in fostering compassion. Some studies have found that religious belief is correlated with compassion towards those less well-off and that it promotes altruism, solidarity, and charity. ${ }^{172}$ However, others have found correlations between religion and intolerance. ${ }^{173}$ In order to distinguish the circumstances under which religiosity contributes to compassion and those under which it fosters intolerance, scholars should more systematically study the interaction between compassion and different aspects of religious belief. Rousseau would lead us to expect a stronger positive relationship between fear of the afterlife or divine retribution and compassion than between, say, church attendance and compassion. The current research suggests that religious anxiety continues to serve as a dangerous but potentially effective tool for extending compassion.

For Rousseau, socioeconomic inequality represented a clear priority and pervasive barrier to compassion. To the extent that contemporary priorities differ from Rousseau's, we would likely want to focus on eliminating other forms of persistent inequality, whether internal (between different religions, races, or ethnicities) or external (between members of different political communities). If that is the case,

171. Claire E. Ashton-James and Jessica L. Tracy, "Pride and Prejudice: How Feelings About the Self Influence Judgments of Others," Personality and Social Psychology Bulletin 38 (2012): 466-76

172. Benjamin R. Knoll, “And Who Is My Neighbor? Religion and Immigration Policy Attitudes," Lournal for the Scientific Study of Religion 48 (2009): 313-31; Ara Norenzayan, Big Gods: How Religion Transformed Cooperation and Conflict (Princeton, N.J.: Princeton University Press, 2014); and Shalom Schwartz and Sipke Huismans, "Value Priorities and Religiosity in Four Western Religions," Social Psychology Ouarterly 58 (1995): 88-10.

173. Paul A. Djupe and Brian R. Calfano, "Religious Value Priming, Threat, and Political Tolerance," Political Research Quarterly 66 (2013): 768-80; Bruce Hunsberger, "Religion and Prejudice: The Role of Religious Fundamentalism, Quest, and Right-Wing Authoritarianism," Lournal of Social Issues 51 (1995): 113-29; and Megan Johnson, Wade C. Rowatt, and Jordan Labouff, "Priming Christian Religious Concepts Increases Racial Prejudice," Social Psychology and Personality Science 1 (2010): 119-26. 
there are good reasons to expect that race and gender provide unique challenges to identification that socioeconomic status leaves open. There is empirical evidence to suggest that individuals have a harder time empathizing with and feeling compassion for out-groups characterized by physical differences such as race. ${ }^{174} \mathrm{~A}$ white cisgender male will have difficulty experiencing fear or anxiety about becoming a trans woman of color, even if he could be led to imagine being discriminated against, marginalized, or stereotyped. Under these circumstances, it may be worthwhile to emphasize socioeconomic status rather than race or gender as a provisional secondbest attempt to extend compassion with the assistance of the more dangerous passions canvassed in this paper. Furthermore, in a world without systematic differences in socioeconomic status between different racial or ethnic groups, that source of difference may register as less problematic than the existing intersection of racial discrimination with socioeconomic inequality.

More empirical research is needed to identify the most effective mechanisms for extending compassion in societies characterized by persistent forms of difference. The goal of this article is to recover a promising model of compassionate citizenship and the dangerous but psychologically plausible tools required for the education of the more privileged members of these societies. In Rousseau's time as in ours, much depends on the willingness of individual parents and educators to take up the difficult task of crafting the right moral and sentimental education.

Alexandra Oprea is a Lecturer in the School of Politics and International Relations at the Australian National University (ANU). Her research interests include public education, the moral and political status of children, and institutional design. She is currently working on a series of articles investigating the appropriate distribution of education power among local and state governments, teachers' unions, parents' associations, non-profits, law courts, and school administrators. She can be reached at alexandraroprea@gmail.com.

174. Xiaojing Xu, et al., "Do You Feel My Pain? Racial Group Membership Modulates Empathic Neural Responses," Journal of Neuroscience 29 (2009): 8525-29. 